\title{
DNA fingerprinting of Bacillus cereus from diverse sources by restriction fragment length polymorphism analysis
}

\author{
Swarnakaran Hemalatha, Narasimhan Banu
}

Department of Biotechnology Vels University, Chennai, India.

Email: hemas81@gmail.com

Received 26 March 2010; revised 10 April 2010; accepted 12 April 2010.

\begin{abstract}
Bacillus cereus is an opportunistic pathogen causing food poisoning manifested by diarrhoeal or emetic syndrome. It is closely related to animal and human pathogens Bacillus anthracis and the insect pathogen Bacillus thuringiensis. In the present study, antibiotic resistance, heavy metal tolerance \& molecular typing of Bacillus cereus from diverse sources such as soil, sewage water, air, fresh water, sea water and milk were studied. Bacillus cereus resistant to Penicillin (10 units/ml) and Amoxycillin $(10 \mu \mathrm{g} / \mathrm{ml})$; sensitive to Cobalt and Mercury even at $1 \mathrm{mM}$ concentration were determined. All the isolate had plasmid ranging in number from 3-5 and their molecular weight ranged from $3.0 \mathrm{~kb}-2.0 \mathrm{~kb}$. Plasmid DNA band specific to 6,557 bp has been found in Bacillus cereus isolated from sewage water, air, fresh water, sea water and milk.
\end{abstract}

Keywords: Bacillus Cereus; Antibiotic Resistance; Heavy Metal Tolerance; RFLP; DNA Finger Printing

\section{INTRODUCTION}

The members of genus Bacillus encompass a great diversity of bacterial species and have a ubiquitous distribution in the environment. Because of their resistant spores and the capacity of vegetative cells to secrete a wide variety of enzymes, this genus is important not only for the production of commercially important bio molecules (insecticides, enzymes, antibiotics, etc.), but also as a source of spoilage or pathogenic organisms transmitted through foods and beverages [1]. Bacillus anthracis, Bacillus cereus, Bacillus thuringiensis are members of the Bacillus cereus group of bacteria. They differ widely in their phenotypes and pathological effects. Bacillus cereus is probably a ubiquitous soil bacterium. In contrast to their differences in phenotypes, by sequence analysis of nine chromosomal genes, Bacillus anthracis can be considered as lineage of Bacillus cereus. This is because of potential of horizontal gene transfer within Bacillus cereus group [2]. The sequencing and analysis of type strain Bacillus cereus ATCC 14579 was reported [3]. The comparative analysis enabled to determine plasmid independent species specific marker. $\mathrm{Ba}$ cillus cereus produces beta-lactamases, unlike Bacillus anthracis, and so is resistant to beta-lactum antibiotics; it is usually susceptible to treatment with Clindamycin, Vanomycin, Gentamycin, Chloramphenicol, and Erythromycin [4].

Bacillus cereus which is ubiquitous in the environment and acting as a source of spoilage through air to food samples needs suitable discriminatory typing methods to facilitate epidemiological investigation. It is of paramount importance to establish a more efficient, easily handled and more objective methodology. In recent times various molecular tools are in experimental protocols. The molecular techniques are major tools for the analysis of micro organisms from food and other biological substances. These techniques provide ways to screen for a broad range of agents in a single test [5]. Molecular techniques are used for rapid differentiation of species and strain identification. Among them RFLP fingerprinting technique is regarded as the most sensitive method for strain identification. RFLP can replace AFLP, RAPD in the estimation of genetic diversity [6]. In the current study, the fingerprinting of Bacillus cereus from diverse sources such as soil, sewage water, air, fresh water, sea water and milk were studied by molecular analysis in parallel with conventional phenotype based methodologies.

\section{MATERIALS AND METHODS}

Six different samples viz., soil, sewage water, air, fresh water, sea water and milk were collected only once from in and around Chennai. The soil, water and milk samples were serially diluted and spread on nutrient agar medium. The bacteria were isolated from air by open plate method. All the plates were kept for 24 hours incubation at $37^{\circ} \mathrm{C}$. The isolated bacterial colonies were purified to homogeneity by quadrant streaking, stored in nutrient agar slants and sub-cultured periodically. The bacteria 
isolated were identified based on physical characterisation and the biochemical tests outlined in Bergey's Manual of Determinative Bacteriology [7].

The sensitivity/resistance of isolates to various antibiotics such as Amoxicillin $(10 \mu \mathrm{g} / \mathrm{ml})$, Chloramphenicol $(30 \mu \mathrm{g} / \mathrm{ml})$, Kanamycin $(30 \mu \mathrm{g} / \mathrm{ml})$, Nalidixic acid (30 $\mu \mathrm{g} / \mathrm{ml})$, Penicillin (10 units $/ \mathrm{ml}$ ) and Streptomycin (25 $\mu \mathrm{g} / \mathrm{ml}$ ) were studied using microbial sensitivity disc (HiMedia) by disc diffusion method. 24 hours culture of Bacillus cereus was swabbed on Nutrient agar plates under sterile condition in laminar air flow and the antibiotics discs of appropriate concentration were placed on agar plates and incubated at $37^{\circ} \mathrm{C}$. After incubation for 24 hours, the plates were observed for growth. A clear zone around the disc was evidence for antibiotic resistance/susceptibility of the isolate. Diameter of the zones of inhibition was measured in millimetres. Nutrient agar plates without antibiotics served as control.

The tolerance of bacterial isolates to various heavy metals such as Cobalt (Cobalt chloride), Iron (Ferrous sulphate), Mercury (Mercury sulphate), Zinc (Zinc sulphate) and Lead (Lead acetate) was studied by inoculating loopful of overnight grown cultures on Nutrient agar plates amended with 1,3 and $5 \mathrm{mM}$ concentrations of heavy metals and incubated at $37^{\circ} \mathrm{C}$. After 24 hours of incubation, the plates were observed for growth. Nutrient agar plates without heavy metal served as control.

The plasmid DNA was isolated based on alkali lysis method [8]. The resulting DNA preparation was quantified by UV spectrophotometer and screened by agarose gel electrophoresis and genetic diversity was estimated by restriction endonuclease digestion.

\section{RESULTS AND DISCUSSION}

Bacillus cereus was isolated from six different samples such as soil, sewage water, air, fresh water, sea water and milk by crowded plate technique. All the isolates were morphologically different in their growth in nutrient agar medium at $37^{\circ} \mathrm{C}$ (Table 1; Figures 1 and 2) but they are biochemically similar. In antibiotic resistance/ sensitivity spectrum, Bacillus cereus isolated from different sources such as soil, sewage water, air, fresh water, sea water and milk samples were sensitive to antibiotics such as Chloramphenicol $(30 \mu \mathrm{g} / \mathrm{ml})$, Kanamycin $(30 \mu \mathrm{g} / \mathrm{ml})$, Nalidixic acid $(30 \mu \mathrm{g} / \mathrm{ml})$ and Streptomycin $(25 \mu \mathrm{g} / \mathrm{ml})$. All Bacillus cereus isolates were resistant to Penicillin (10 units $/ \mathrm{ml}$ ) and Amoxycillin $(10 \mu \mathrm{g} / \mathrm{ml})$ (Table 2; Figures 3 and 4). The zone of inhibition of Amoxycillin, Chloramphenicol, Kanamycin, Nalidixic acid, Penicillin and Streptomycin against different isolates of Bacillus cereus was measured in millimetres using standard recommendations. The zone of inhibition for Chloramphenicol, Kanamycin, Nalidixic acid and Streptomycin against Bacillus cereus obtained from soil was $9 \mathrm{~mm}, 7 \mathrm{~mm}, 4$ $\mathrm{mm}$ and $8 \mathrm{~mm}$ respectively. The zone of inhibition for Chloramphenicol, Kanamycin, Nalidixic acid and Streptomycin against Bacillus cereus obtained from sewage water was $9 \mathrm{~mm}, 8 \mathrm{~mm}, 6 \mathrm{~mm}$ and $8 \mathrm{~mm}$ respectively. The zone of inhibition for Chloramphenicol, Kanamycin, Nalidixic acid and Streptomycin against Bacillus cereus obtained from air was $7 \mathrm{~mm}, 7 \mathrm{~mm}, 8 \mathrm{~mm}$ and $9 \mathrm{~mm}$ respectively. The zone of inhibition for Chloramphenicol, Kanamycin, Nalidixic acid and Streptomycin against $B a-$ cillus cereus obtained from fresh water was $8 \mathrm{~mm}, 6 \mathrm{~mm}$,

Table 1. Colonial morphology of Bacillus cereus isolates from diverse sources (Jonathan, 2004).

\begin{tabular}{|c|c|c|c|c|c|c|c|}
\hline \multirow{2}{*}{$\begin{array}{l}\text { S. } \\
\text { No }\end{array}$} & \multirow{2}{*}{$\begin{array}{c}\text { Cultural } \\
\text { characteristics }\end{array}$} & \multicolumn{6}{|c|}{ Bacillus cereus Isolate } \\
\hline & & Soil & $\begin{array}{l}\text { Sewage } \\
\text { Water }\end{array}$ & Air & Fresh Water & Sea Water & Milk \\
\hline 1. & Medium & Nutrient Agar & Nutrient Agar & Nutrient Agar & Nutrient Agar & Nutrient Agar & Nutrient Agar \\
\hline 2. & Colour & Creamy & Creamy & White & White & Creamy & Creamy \\
\hline 3. & Shape & Spherical & Circular & Circular & Circular & Circular & Spherical \\
\hline 4. & Size & $1.6 \mathrm{~mm}$ & $0.3 \mathrm{~mm}$ & $0.4 \mathrm{~mm}$ & $0.3 \mathrm{~mm}$ & $0.9 \mathrm{~mm}$ & $1.5 \mathrm{~mm}$ \\
\hline 5. & Surface & Dull and dry & Dull & Dull & Dull & Dull & Dull \\
\hline 6. & Edge & Rhizoid & Entire & Entire & Entire & Entire & Undulate \\
\hline 7. & Opacity & Opaque & Opaque & Translucent & Translucent & Opaque & Opaque \\
\hline 8. & Degree of Growth & Profuse & Moderate & Moderate & Moderate & Moderate & Profuse \\
\hline 9. & Elevation & Flat & Low convex & Low convex & Low convex & Low Convex & Low convex \\
\hline 10. & Consistency & Butyrous & Friable & Friable & Friable & Friable & Friable \\
\hline 11. & Emulsifiability & Difficult & Easy & Easy & Easy & Easy & Easy \\
\hline
\end{tabular}




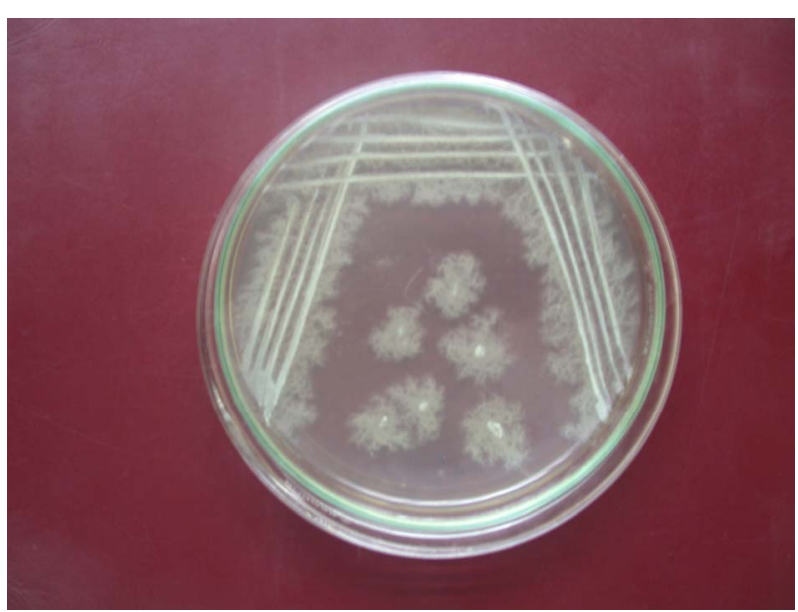

Bacillus cereus from Soil

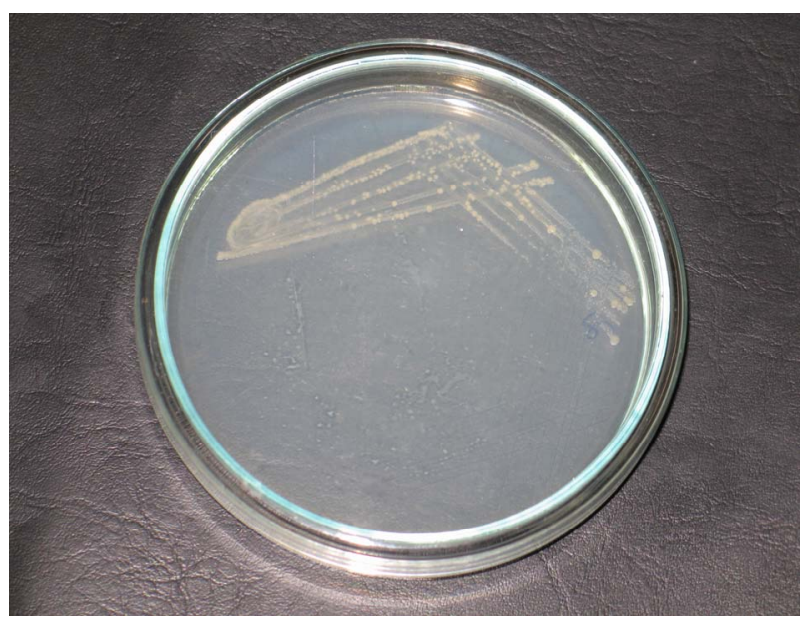

Bacillus cereus from Sewage water

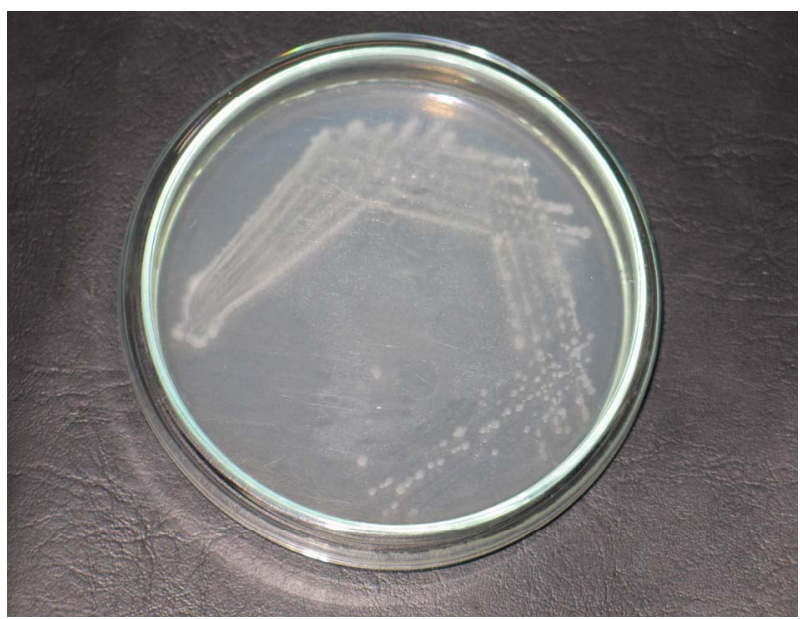

Bacillus cereus from Air

Figure 1. Bacillus cereus isolate from diverse sources.

$9 \mathrm{~mm}$ and $7 \mathrm{~mm}$ respectively. The zone of inhibition for Chloramphenicol, Kanamycin, Nalidixic acid and Streptomycin against Bacillus cereus obtained from sea water

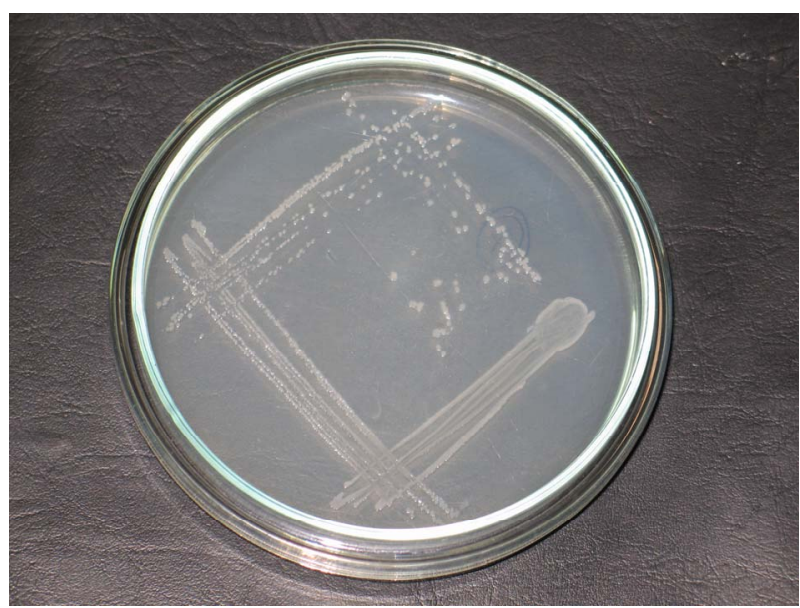

Bacillus cereus from Fresh water

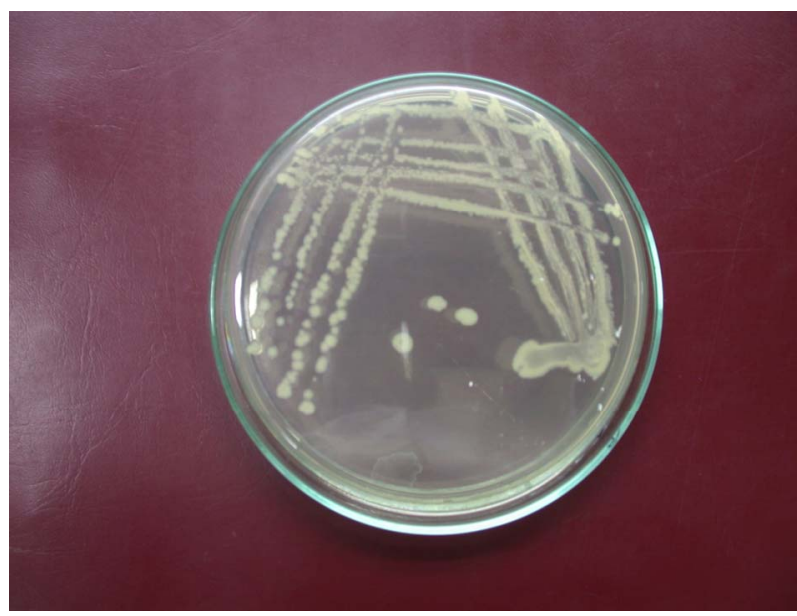

Bacillus cereus from Sea water

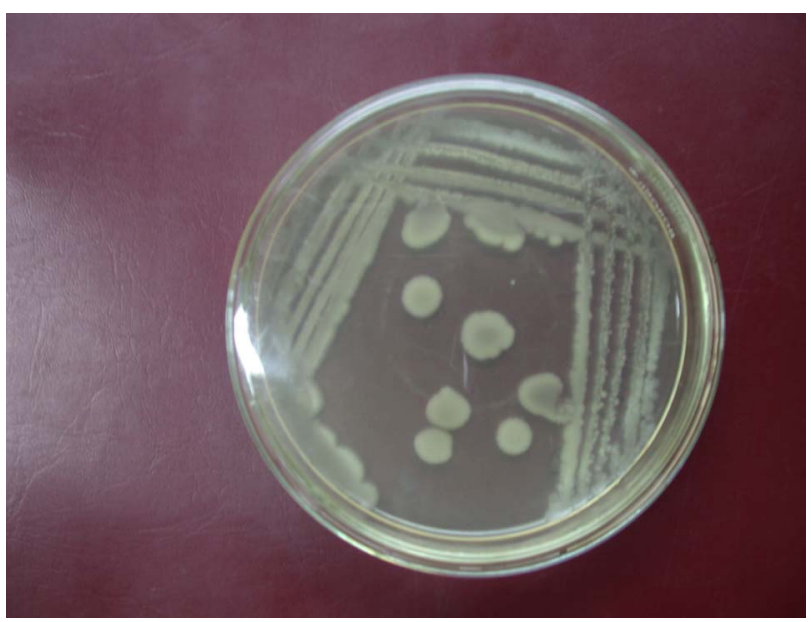

Bacillus cereus from Milk

Figure 2. Bacillus cereus isolate from diverse sources.

was $9 \mathrm{~mm}, 6 \mathrm{~mm}, 6 \mathrm{~mm}$ and $7 \mathrm{~mm}$ respectively. The zone of inhibition for Chloramphenicol, Kanamycin, Nalidixic acid and Streptomycin against Bacillus cereus 

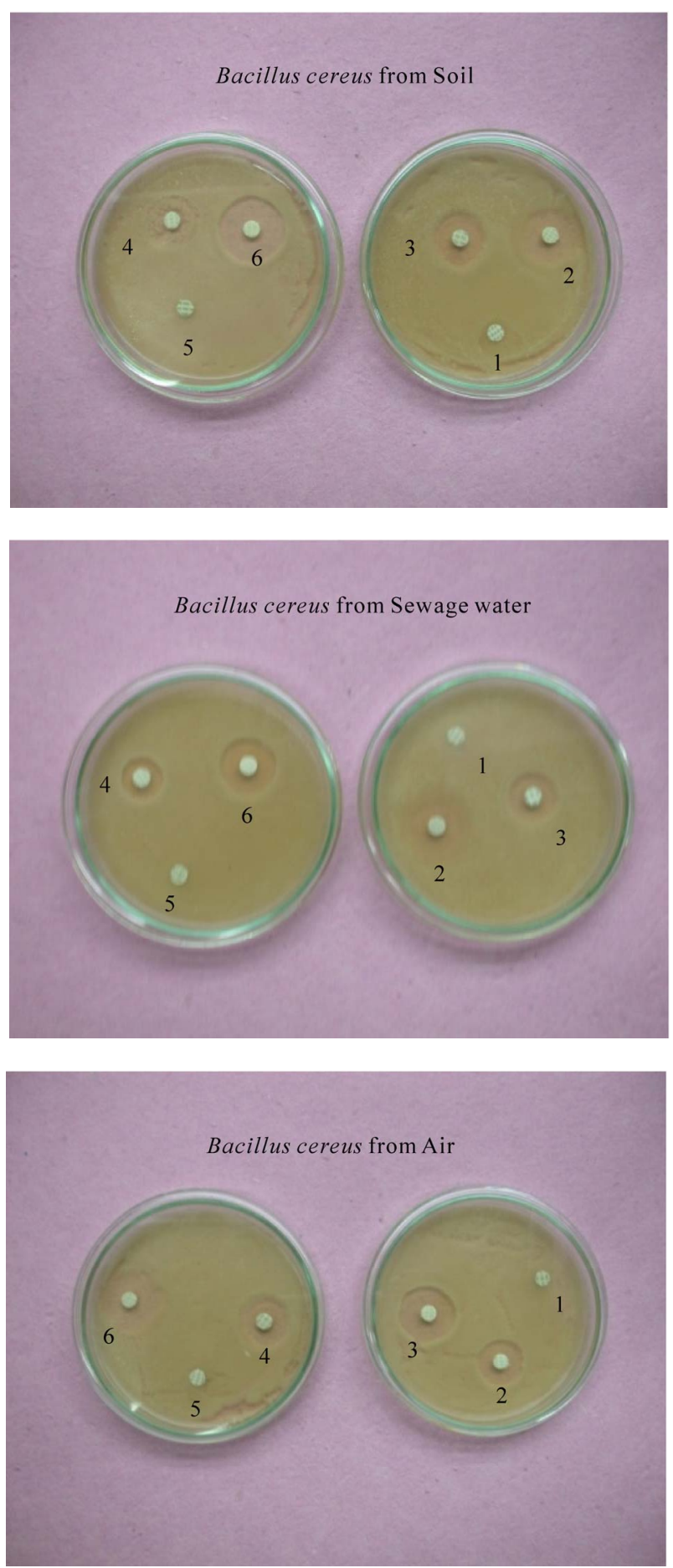

1. Amoxycillin, 2. Chloramphenicol, 3. Kanamycin, 4. Nalidixic acid, 5. Penicillin, 6. Streptomycin

Figure 3. Antibiotic resistance/sensitivity spectrum of Bacillus cereus isolate from diverse sources.

obtained from milk was $9 \mathrm{~mm}, 6 \mathrm{~mm}, 7 \mathrm{~mm}$ and $7 \mathrm{~mm}$ respectively. Except Bacillus cereus from air and fresh water all the other Bacillus cereus isolate have shown maximum zone of inhibition $(9 \mathrm{~mm})$ for Chlorampheni-
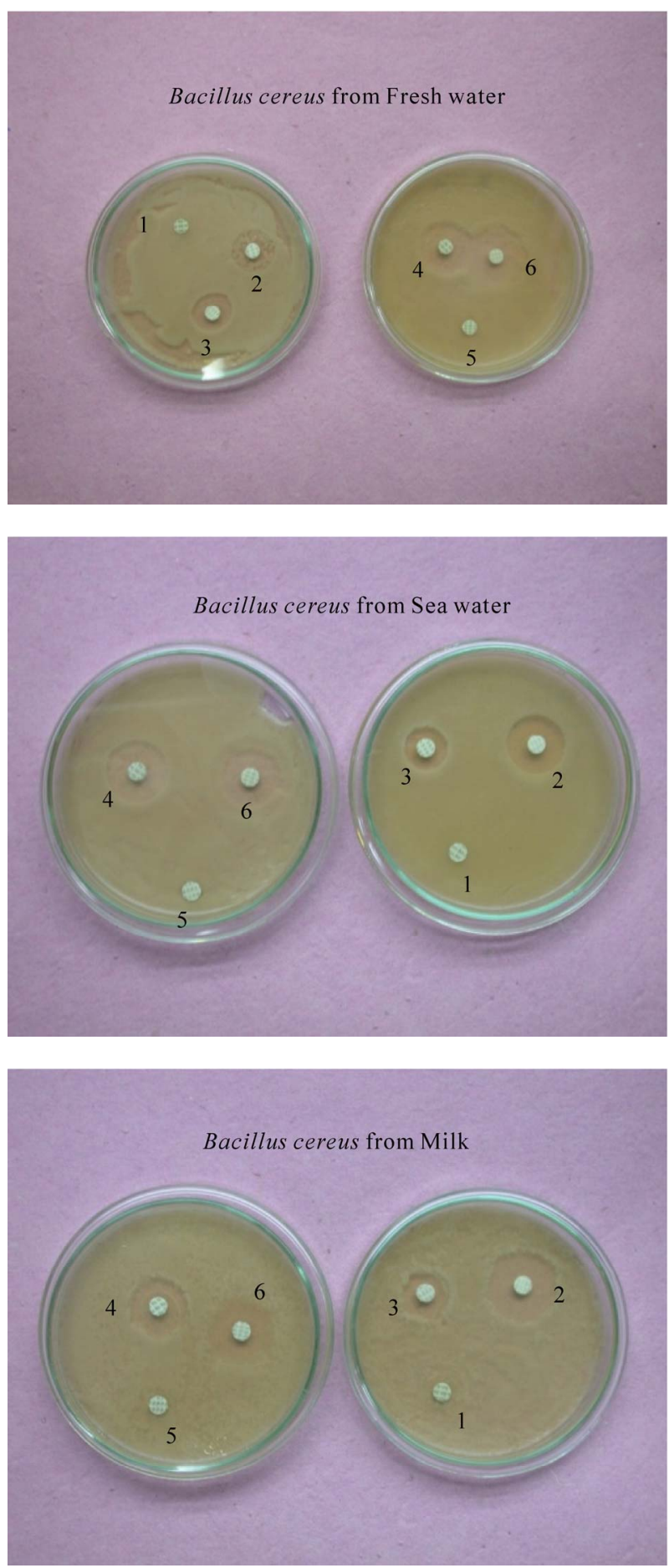

1. Amoxycillin, 2. Chloramphenicol, 3. Kanamycin, 4. Nalidixic acid, 5. Penicillin, 6. Streptomycin

Figure 4. Antibiotic resistance/sensitivity spectrum of Bacillus cereus isolate from diverse sources.

col (Table 3). Therefore Chloramphenicol can be recommended for Bacillus cereus infections. Plasmid mediated bacterium will exert resistance towards antimicrobials [9]. Therefore all the Bacillus cereus isolate should 
Table 2. Antibiotic Resistance /Sensitivity spectrum of Bacillus cereus isolate from diverse sources

\begin{tabular}{|c|c|c|c|c|c|c|c|}
\hline \multirow{2}{*}{ Antibiotics } & \multirow{2}{*}{ Concentration $(\mu \mathrm{g} / \mathrm{ml})$} & \multicolumn{6}{|c|}{ Bacillus cereus Isolate } \\
\hline & & Soil & $\begin{array}{l}\text { Sewage } \\
\text { Water }\end{array}$ & Air & $\begin{array}{l}\text { Fresh } \\
\text { Water }\end{array}$ & Sea Water & Milk \\
\hline Amoxycillin & 10 & - & - & - & - & - & - \\
\hline Chloramphenicol & 30 & + & + & + & + & + & + \\
\hline Kanamycin & 30 & + & + & + & + & + & + \\
\hline Nalidixic acid & 30 & + & + & + & + & + & + \\
\hline Penicillin & 10 & - & - & - & - & - & - \\
\hline Streptomycin & 25 & + & + & + & + & + & + \\
\hline
\end{tabular}

- Sensitive

+ Resistant

Table 3. The measurement of zone of inhibition of antibiotics against Bacillus cereus isolate from diverse sources.

\begin{tabular}{|c|c|c|c|c|c|c|}
\hline \multirow{2}{*}{$\begin{array}{c}\text { Bacillus } \\
\text { cereus } \\
\text { Isolate }\end{array}$} & \multicolumn{6}{|c|}{ Antibiotics ( $\mu \mathrm{g} / \mathrm{ml})$} \\
\hline & Amoxycillin & Chloramphenicol & Kanamycin & Nalidixic acid & Penicillin & Streptomycin \\
\hline Soil & $-\mathrm{ve}$ & $9 \mathrm{~mm}$ & $7 \mathrm{~mm}$ & $4 \mathrm{~mm}$ & $-\mathrm{ve}$ & $8 \mathrm{~mm}$ \\
\hline $\begin{array}{c}\text { Sewage } \\
\text { Water }\end{array}$ & $-\mathrm{ve}$ & $9 \mathrm{~mm}$ & $8 \mathrm{~mm}$ & $6 \mathrm{~mm}$ & $-\mathrm{ve}$ & $8 \mathrm{~mm}$ \\
\hline Air & $-\mathrm{ve}$ & $7 \mathrm{~mm}$ & $7 \mathrm{~mm}$ & $8 \mathrm{~mm}$ & $-\mathrm{ve}$ & $9 \mathrm{~mm}$ \\
\hline $\begin{array}{l}\text { Fresh } \\
\text { Water }\end{array}$ & $-\mathrm{ve}$ & $8 \mathrm{~mm}$ & $6 \mathrm{~mm}$ & $9 \mathrm{~mm}$ & $-\mathrm{ve}$ & $7 \mathrm{~mm}$ \\
\hline Sea Water & $-\mathrm{ve}$ & $9 \mathrm{~mm}$ & $6 \mathrm{~mm}$ & $6 \mathrm{~mm}$ & $-\mathrm{ve}$ & $7 \mathrm{~mm}$ \\
\hline Milk & $-\mathrm{ve}$ & $9 \mathrm{~mm}$ & $6 \mathrm{~mm}$ & $7 \mathrm{~mm}$ & $-\mathrm{ve}$ & $7 \mathrm{~mm}$ \\
\hline
\end{tabular}

- ve Negative

possess plasmid DNA in their genetic makeup.

Bacillus cereus was also tested for their heavy metal tolerance. Five heavy metals namely Cobalt (Cobalt chloride), Iron (Ferrous sulphate), Mercury (Mercury sulphate), Zinc (Zinc sulphate) and Lead (Lead acetate) at a concentration of 1-5 mM were selected to conduct present study. All the isolates were sensitive to Cobalt and Mercury (Table 4; Figures 5, 6 and 7). Bacillus cereus isolated from soil and air was sensitive to Iron at $5 \mathrm{mM}$ concentration. Bacillus cereus isolated from fresh water, sewage water and milk were sensitive to zinc at 3 $\mathrm{mM}$ concentration. All the isolate were sensitive to Zinc at $5 \mathrm{mM}$ concentration. Being sensitive no growth was observed in their plates. These results revealed that the presence of heavy metal such as Cobalt and Mercury even at $1 \mathrm{mM}$ concentration was highly toxic to Bacillus cereus which is distributed widely in the environment and food samples and they will pose a serious threat to their metabolism in the natural environment. All the isolates showed resistance to Lead. This could be attributed due to the presence of plasmid. Transferable plasmid encodes resistance to various heavy metals [10]. In the present work, a high frequency of resistance to heavy metal was observed in Bacillus cereus isolated from sewage water.

Based on antibiotic resistance/susceptibility spectrum and heavy metal tolerance spectrum of Bacillus cereus isolated from different sources, it was not possible to identify whether they belonged to same group or not. Second level information for a bacterial cell other than sequencing of bacterial genome can be obtained only by using any of the molecular techniques. Therefore in the present study Restriction Fragment Length Polymorphism (RFLP) was analysed to estimate genetic diversity of Bacillus cereus from different sources and usefulness of RFLP as an identification tool in the genus at sub species level.

The native plasmid profile of all the six Bacillus cereus isolates after alkali lysis was observed on 1\% agarose gel electrophoresis (Figure 8). All the Bacillus cereus isolate have shown plasmid number ranging from 3-5. Bacillus cereus isolated from sewage water has 5 

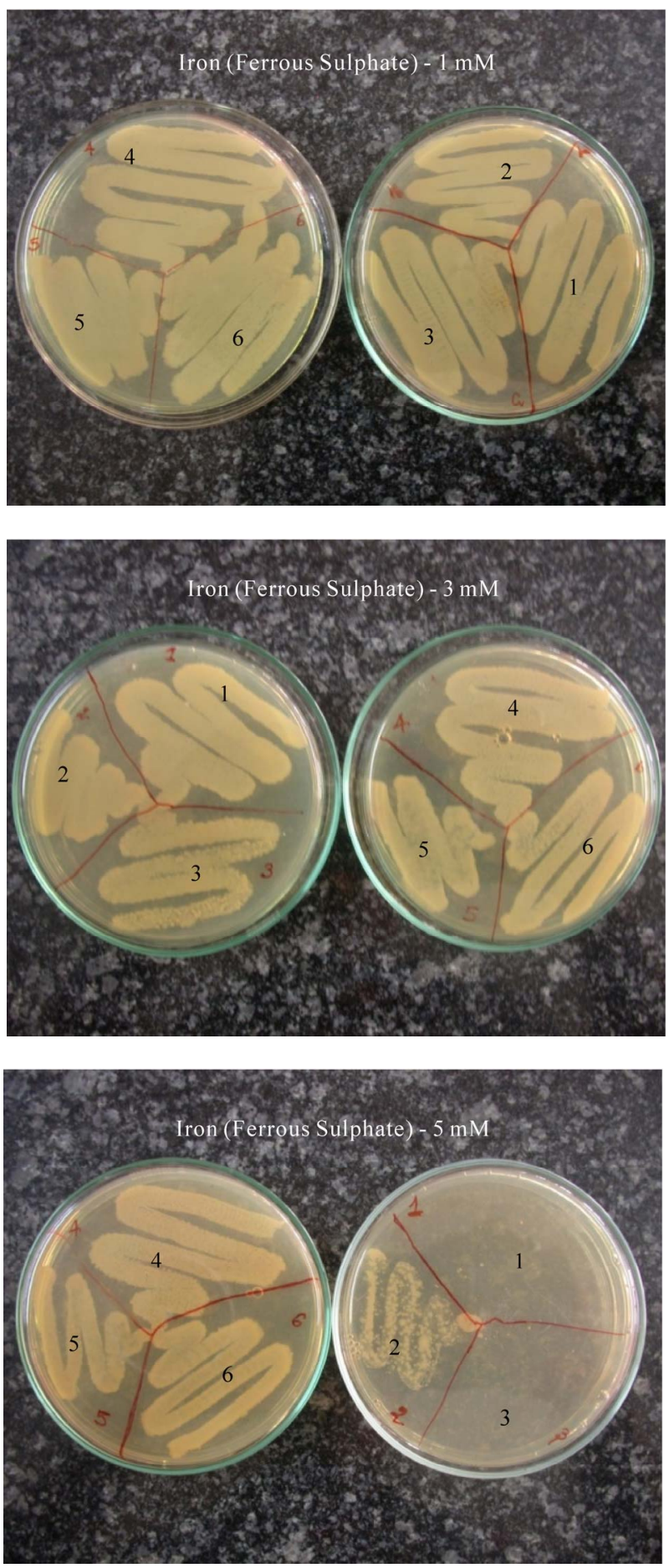

1. Bacillus cereus from Soil, 2. Bacillus cereus from Sewage water, 3 . Bacillus cereus from Air, 4. Bacillus cereus from Fresh water, 5. Bacillus cereus from Sea water, 6. Bacillus cereus from Milk

Figure 5. Heavy Metal tolerance spectrum of Bacillus cereus isolate from diverse sources.

plasmid in number. The size of the plasmid DNA of different Bacillus cereus ranged from $3.0 \mathrm{~kb}-2.0 \mathrm{~kb}$ type as compared with molecular weight marker DNA. Distinct
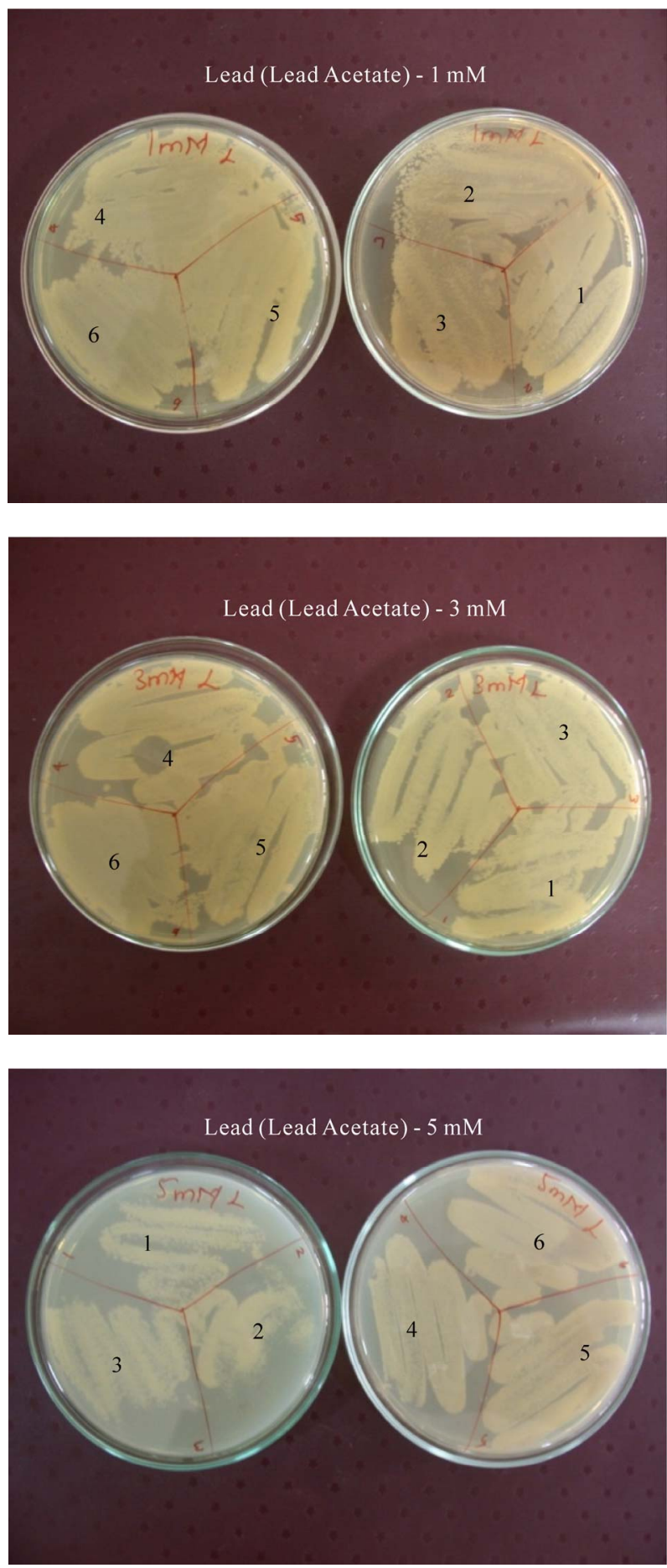

1. Bacillus cereus from Soil, 2. Bacillus cereus from Sewage water, 3 . Bacillus cereus from Air, 4. Bacillus cereus from Fresh water, 5. Bacillus cereus from Sea water, 6. Bacillus cereus from Milk

Figure 6. Heavy Metal tolerance spectrum of Bacillus cereus isolate from diverse sources.

band pattern corresponding to $2.0 \mathrm{~kb}$ DNA was seen in Bacillus cereus isolated from soil, sewage water and fresh water. Though they are isolated from different 
Table 4. Heavy Metal Tolerance Spectrum of Bacillus cereus isolate from different sources.

\begin{tabular}{|c|c|c|c|c|c|c|c|}
\hline \multirow{2}{*}{ Heavy metals } & \multirow{2}{*}{$\begin{array}{c}\text { Concentration ( } \mu \mathrm{g} \\
/ \mathrm{ml})\end{array}$} & \multicolumn{6}{|c|}{ Bacillus cereus Isolate } \\
\hline & & Soil & $\begin{array}{c}\text { Sewage } \\
\text { water }\end{array}$ & Air & $\begin{array}{l}\text { Fresh } \\
\text { water }\end{array}$ & Sea water & Milk \\
\hline \multirow{3}{*}{$\begin{array}{c}\text { Cobalt(Cobalt chlo- } \\
\text { ride) }\end{array}$} & 1 & - & - & - & - & - & - \\
\hline & 3 & - & - & - & - & - & - \\
\hline & 5 & - & - & - & - & - & - \\
\hline \multirow{3}{*}{$\begin{array}{l}\text { Iron (Ferrous sul- } \\
\text { phate) }\end{array}$} & 1 & + & + & + & + & + & + \\
\hline & 3 & + & + & + & + & + & + \\
\hline & 5 & - & + & - & + & + & + \\
\hline \multirow{3}{*}{$\begin{array}{l}\text { Mercury (Mercury } \\
\text { sulphate) }\end{array}$} & 1 & - & - & - & - & - & - \\
\hline & 3 & - & - & - & - & - & - \\
\hline & 5 & - & - & - & - & - & - \\
\hline \multirow{3}{*}{ Lead (Lead acetate) } & 1 & + & + & + & + & + & + \\
\hline & 3 & + & + & + & + & + & + \\
\hline & 5 & + & + & + & + & + & + \\
\hline \multirow{3}{*}{ Zinc (Zinc sulphate) } & 1 & + & + & + & + & + & + \\
\hline & 3 & + & + & + & - & - & - \\
\hline & 5 & - & - & - & - & - & - \\
\hline
\end{tabular}

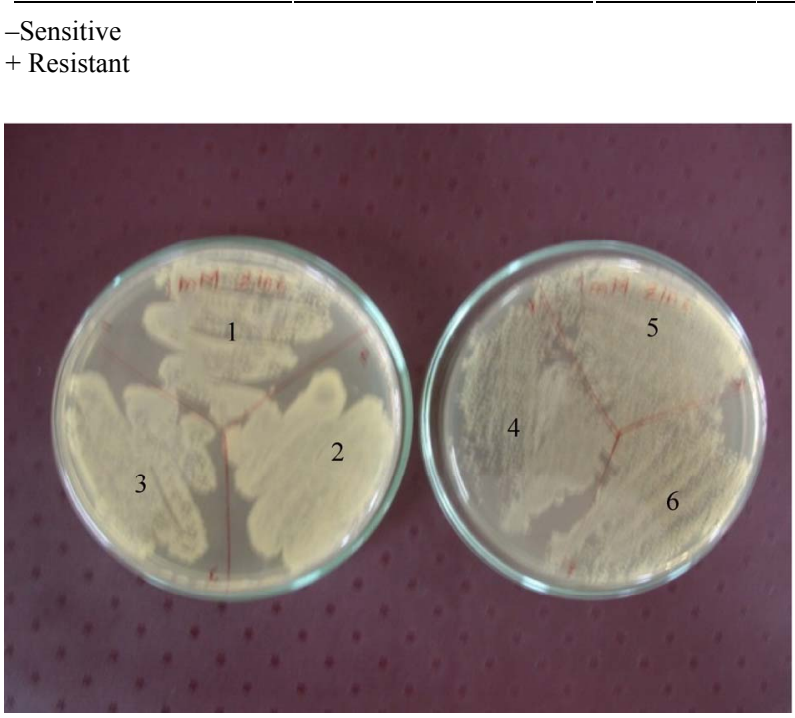

Zinc (Zinc Sulphate) $-1 \mathrm{mM}$

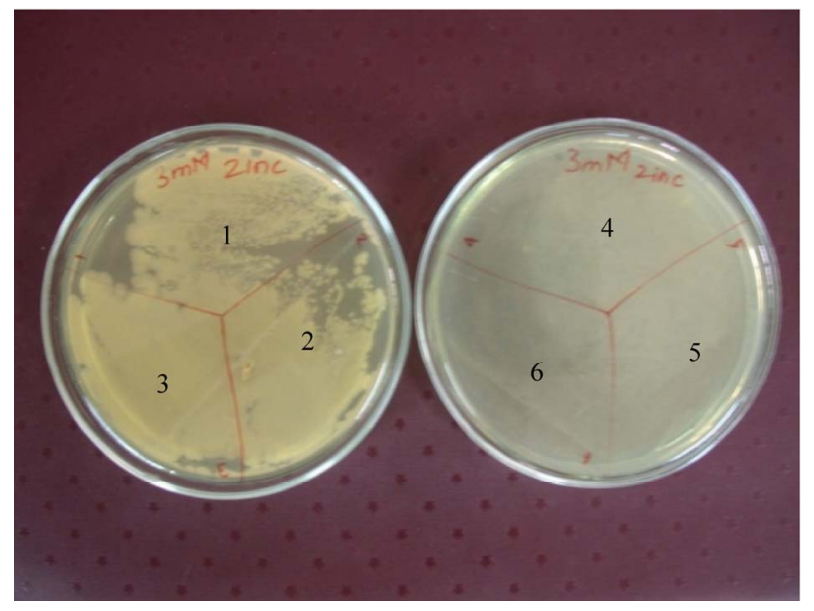

Zinc (Zinc Sulphate) $-3 \mathrm{mM}$

1. Bacillus cereus from Soil, 2. Bacillus cereus from Sewage water, 3. Bacillus cereus from Air, 4. Bacillus cereus from Fresh water, 5. Bacillus cereus from Sea water, 6. Bacillus cereus from Milk

Figure 7. Heavy Metal tolerance spectrum of Bacillus cereus isolate from diverse sources.

sources, all the isolates have shown similar molecular weight plasmid DNA. The DNA was quantified using UV spectrophotometry. All the isolates had DNA concen- tration ranging from $0.372 \mu \mathrm{g} / \mathrm{ml}-0.79 \mu \mathrm{g} / \mathrm{ml}$ (Table 5). Bacillus cereus isolated from air had the highest plasmid DNA concentration $(0.802 \mu \mathrm{g} / \mathrm{ml})$ followed by 


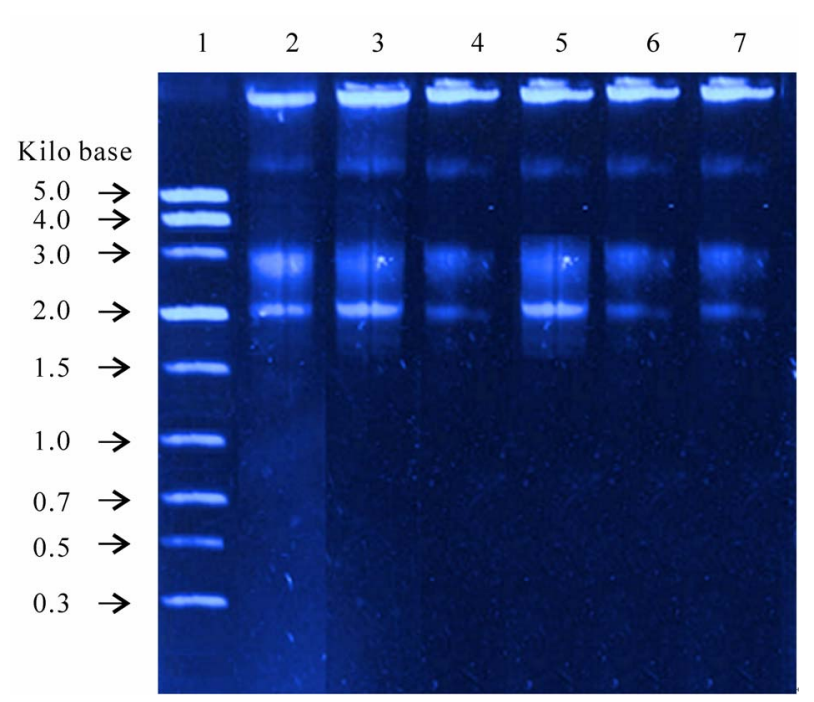

Lane 1-1 Kb DNA ladder, Lane 2-Bacillus cereus from Soil, Lane 3 -Bacillus cereus from Sewage water, Lane 4-Bacillus cereus from Air, Lane 5-Bacillus cereus from Fresh water, Lane 6-Bacillus cereus from Sea water, Lane 7-Bacillus cereus from Milk

Figure 8. Gel photograph showing plasmid DNA profile of Bacillus cereus.

Table 5. Determining concentration and purity of DNA.

\begin{tabular}{ccccc}
\hline $\begin{array}{c}\text { Bacillus } \\
\text { cereus } \\
\text { isolate }\end{array}$ & $\begin{array}{c}\text { Absorbance } \\
\text { at OD 260 nmat OD 280 nm }\end{array}$ & $\begin{array}{c}\text { Absorbance } \\
\text { A260/280 }\end{array}$ & $\begin{array}{c}\text { Concentration } \\
\text { of DNA }(\boldsymbol{\mu g} / \mathbf{m l})\end{array}$ \\
\hline $\begin{array}{c}\text { Soil } \\
\begin{array}{c}\text { Sewage } \\
\text { water }\end{array}\end{array}$ & 0.217 & 0.122 & 1.7 & 0.5425 \\
$\quad$ Air & 0.176 & 0.093 & 1.8 & 0.44 \\
$\begin{array}{c}\text { Fresh } \\
\text { water }\end{array}$ & 0.149 & 0.182 & 1.76 & 0.802 \\
Sea water & 0.316 & 0.175 & 1.8 & 0.79 \\
Milk & 0.170 & 0.090 & 1.8 & 0.425 \\
\hline
\end{tabular}

Bacillus cereus from sea water $(0.79 \mu \mathrm{g} / \mathrm{ml})$ and Bacillus cereus from soil $(0.54 \mu \mathrm{g} / \mathrm{ml})$. The DNA obtained by alkali lysis was sufficient to carry out restriction digestion since only nanogram quantity is required to carry out RFLP. The DNA obtained was free of protein contaminants and RNA since absorbance ratio between 260 and $280 \mathrm{~nm}$ was 1.8 which determines pure DNA.

Type II restriction endonucleases are most important tools in gene manipulation techniques. Hind III are very useful in modern science particularly in DNA sequencing and mapping. Hind III restriction endonuclease performs very specific cleavage of DNA and they cleave only at their specific recognition site. Hind III utilizes a common mechanism of recognition and catalyses of DNA found in other type II enzymes such as Eco RI, Bam HI and Bgl II. Hind III restriction enzyme is sufficient to generate unique fragment of DNA molecule.

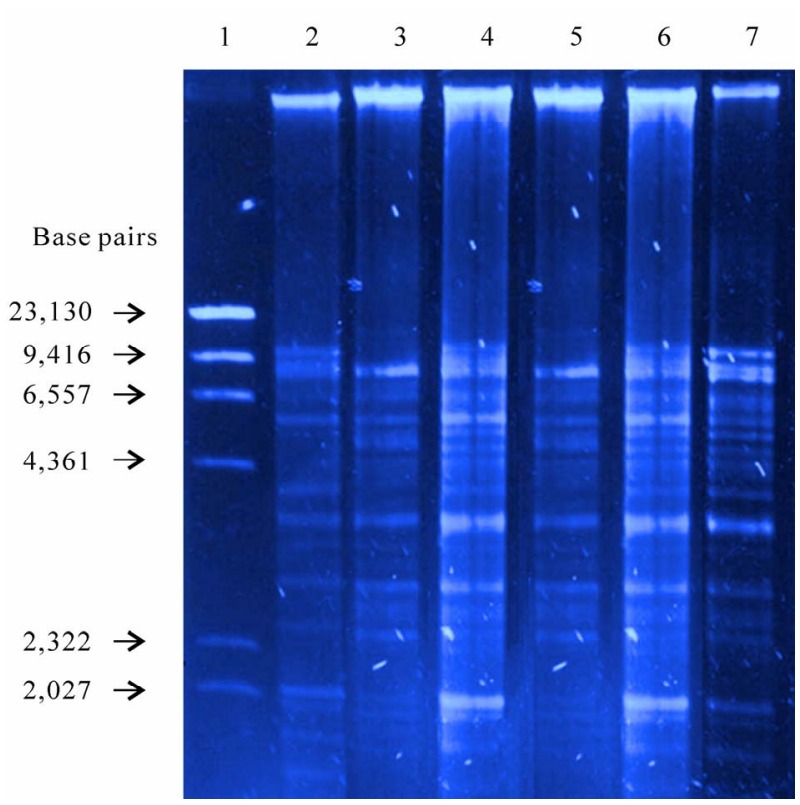

Lane $1-\lambda$ / Hind III digest, Lane 2-Bacillus cereus from Soil, Lane 3 -Bacillus cereus from Sewage water, Lane 4-Bacillus cereus from Air, Lane 5-Bacillus cereus from Fresh water, Lane 6-Bacillus cereus from Sea water, Lane 7-Bacillus cereus from Milk

Figure 9. RFLP analysis of Bacillus cereus isolates.

Therefore in the present study, plasmid DNA was digested with Hind III restriction enzyme to analyse the Restriction Fragment Length Polymorphism. The Hind III restriction of total plasmid resulted into 12-17 bands in each isolate (Figure 9). Fragment length of all the isolate lies between 23,130 bp and 2,027 bp. Bacillus cereus isolate from soil, air, sea water and milk have shown bands corresponding to 9,416 bp. Plasmid DNA band specific to 6,557 bp has been found in Bacillus cereus isolated from sewage water, air, fresh water, sea water and milk. A clear distinct band corresponding to 2,027 bp has been observed in Bacillus cereus from air and sea water. Bacillus cereus from soil and milk have shown different restriction pattern to Bacillus cereus from air, sea water, sewage water and fresh water. $B a-$ cillus cereus from air and sea water belonged to the same group whereas Bacillus cereus from sewage water and freshwater are of same group. RFLP analysis has shown variations among the different isolates but the level of RFLP diversity among different Bacillus cereus isolate was low. This may be due to non specificity of restriction endonuclease.

\section{CONCLUSIONS}

The molecular approach in present study is complementary to traditional methods. RFLP based molecular approach has provided ways to screen whether the same isolate from diverse origin belong to same group or not in a single test rather than time consuming conventional 
phenotype based methodologies. The knowledge of genetic diversity based on molecular approach will facilitate the study of relationship between them. Therefore, the approach provided here is applicable to DNA fingerprinting of micro organisms. But in future, amplification of any specific gene and their restriction digestion can be carried out which could enable to detect polymorphism in same isolate from diverse origin to a high frequency level.

\section{REFERENCES}

[1] Kramer, J.M. and Gilbert, R.J. (1992) Bacillus cereus gastroenteritis. In: Tu, A.T. Ed., Food poisoining, Handbook of Natural toxins, 7, 119-153.

[2] Helgason, E., Okstad, O.A., Caugant, D.A., Johansen, H.A., Fouet, A., Mock M. and Hegna, I. (2000) Bacillus anthracis, Bacillus cereus and Bacillus thuringiensis one species on the basis of genetic evidence. Applied and Environmental Microbiology, 66(6), 2627-2630.

[3] Ivanova, N., Sorokin, A., Galleron, I.A., Candelon, B., Bhattacharya, A. K., Reznik, G., Mikhailova, N., Lapidus, A., Chu, L., Mazur, M., Goltsman, E., Walnus, T.L., Grechkin, G., Pusch, M., Haselkorn, M., Fonstein, S., Ehrlich, Y., Overbeek, R. and Kyrpides, N. (2003) Genome sequence of Bacillus cereus and comparative analysis with Bacillus anthracis. Nature, 423, 87-91.

[4] Drobniewski, F.A. (1998) Bacillus cereus and related species. Clinical Microbiology Reviews, 6(4), 324-328.

[5] Field, D. and Wills, C. (1998) Abundant micro satellite polymorphism in Saccharomyces cerevisiae, and the different distributions of micro satellite in eight prokaryotes and S.cerevisiae, results from strong mutation pressures and a variety of selective forces. Proceedings of National Academy of Sciences, USA, 95(4), 1647-1652.

[6] Lu, J., Knox, M.R., Ambrose, M.J., Brown J.K.M. and Ellis, T.H.N. (1996) Comparative analysis of genetic diversity in pea assessed by RFLP and PCR based methods. Theoritical and Applied Genetics, 93(7), 1103-1111.

[7] Williams and Wilkins. (1994) Bergy's Manual of Determinative Bacteriology. In: Williams and Wilkins, 9th Edition.

[8] Sambrook, J. and David, W.R. (2001) Molecular cloning: A laboratory manual. Cold spring Harbor Laboratory Press, Newyork.

[9] Forster, T.J. (1983) Plasmid mediated resistance to antimicrobial and toxic metal in bacteria. Microbiology Review, 47(3), 361-409.

[10] Ghosh, A., Singh, A., Ramteke, P. and Singh, V. (2000) Characterisation of large plasmid encoding resistance to toxic heavy metals in Salmonella abortus equi. Biochemical and Biophysical Research Communications, 272(1), 6-11. 